\title{
IMPLEMENTATION OF ARTICLE 4 ACT NO. 24 /2011 ON BPJS THE NATIONAL HEALTH INSURANCE SYSTEM TO IMPROVE HEALTH SERVICES
}

\author{
Hilda Yunita Sabrie \\ Private Law Departement, Faculty of Law, \\ Airlanga University \\ hilda@fh.unair.ac.id.
}

\author{
Prawitra Thalib \\ Private Law Departement, Faculty of Law, \\ Airlanga University \\ prawitra@fh.unair.ac.id
}

\begin{abstract}
Badan Penyelenggara Jaminan Sosial or often in short BPJS is a non-profit legal entity established in the framework of organizing social security related to health and employment. BPJS is in the form of the mandate Act No. 24 / 2011 About BPJS. Especially for BPJS Health, the purpose of this BPJS is to realize the implementation of the provision of appropriate health insurance for each participant and / or family members as the fulfillment of the basic needs of life of the people of Indonesia. Next expected people in Indonesia get a guarantee of health services and hospitals. This is also similar as mandated in the Constitution of the Republic of Indonesia of 1945 (UUD 1945). But since the existence of BPJS as the only legal entity providing health care for the community in the form of compulsory social insurance, there are still grievances experienced by the community in this case as the insured. This matter should get attention or supervision on whether the national social security system in BPJS apply in accordance with applicable legislation. This needs to be examined more deeply because the procedures seen by BPJS seem very complicated. In
\end{abstract}

addition whether the principles that exist in the BPJS has been properly applied in legislation or in practice. Still, the government must continue to make better, more effective and efficient reforms.

Keywords : BPJS, Governance, Insurance

\section{INTRODUCTION}

The establishment of BPJS was initiated from the mandate of Act no. 40 of 2004 on the National Social Security System (hereinafter referred to as Act No. 40/2004). Whereas in Act No.40 / 2004, BPJS is a legal entity established to administer social security programs (Article 1 point 6), non-profit legal entities (Article 4 and general explanations) and in the case of establishment of BPJS shall be by Act (Article 5 paragraph 1). Based on Article 52 paragraph 2 of Act no. 40/2004, the deadline for the adjustment and completion of all provisions governing BPJS is 19 October 2009 which is 5 years since Act no. 40/2004 was enacted. The deadline for the enactment of the Act on BPJS specified in Act no. 40 of 2004 cannot be fulfilled by the Government. So the House of Representatives took the 
initiative to resolve this issue through the National Legislation Program 2010 to draft a bill on BPJS. The House of Representatives submitted a bill on BPJS to the Government on October 8, 2010 to be discussed with them. Then on October 28, 2011, the Bill on BPJS was approved to be legalized. The House of Representatives submitted a bill on BPJS to the President on November 7, 2011. The Government enacted BPJS on November 25, 2011.[1]

The increasing of public participation in the JKN program is a big responsibility for the government to carry out its obligation to provide good health services to BPJS participants. It has also been regulated in Article $28 \mathrm{H}$ paragraph (3) of the 1945 Constitution which stipulates that everyone is entitled to social security which enables his complete development as a dignified human being. The provision of Article $28 \mathrm{H}$ paragraph (3) of the 1945 Constitution is mainly related to the protection of human rights (hereinafter referred to as human rights). Social security is one form of human rights. Constitutionally, the social security is related to the state's responsibility to its people.

After the enactment of the Act of BPJS, with a very minimalist preparation, the system is not designed so well. So, at the beginning, the presence is very reasonable still get a lot of complaints from the community. Even often people still compare the types of social insurance compulsory earlier such as ASKES, JAMSOSTEK, ASABRI AND TASPEN perceived better in terms of services, systems and facilities. As BPJS becomes the only JKN in Indonesia, there are several problems, such as the deficit of BPJS for the last 3 years.

In practice there is data that since 2014-2015, BPJS has experienced a loss of Rp. 6 trillion - Rp. 7 trillion.[2] There are two things that become the constraint factor why BPJS always have potential to lose. The first is the difference of benefit cost with the member contribution (BPJS) and the second is the instant registration pattern done by the candidate of BPJS member. This means that the prospective member of BPJS began to register to be the member of BPJS is already in an unhealthy condition. On March 1, 2016, to reduce or minimize the loss of BPJS, the government sets a special premium rate increase for the independent member, as stipulated in the Presidential Regulation no. 19/2016 On the Second Amendment for the Presidential Regulation No.12 / 2013 on Health Insurance. However, the increasing of due does not guarantee that BPJS will get off its deficit. Precisely, it is increasing the burden because the members may expect an improvement over the shortcomings that have been complained by the member of BPJS.

After looking at the constraints mentioned above, then the research requires to study more deeply on the workflow of the prospective member of BPJS registering himself as the member of BPJS up to when the member submit the claims to BPJS. What procedures should be done, what obligations should be done by the parties in this case the BPJS and BPJS member. About what rights are obtained by the BPJS member up to the special rules that must be known by the participants to claim his paid. This should be clearly known, especially by BPJS member and should not deviate from the principles of insurance and, of course, it should not conflict with existing legislation

\section{SYSTEM IN THE NATIONAL HEALTH ASSURANCE IMPLEMENTED BY BPJS}

BPJS is a legal entity formed to organize a social security program which is a mandate of Act no. 40/2004. The social security is one form of social protection to ensure that all people are able to meet their basic needs in terms of health. This program is one of the government programs aimed at providing certainty of 
protection and social welfare for all Indonesian people. As contained in Article 10 of the BPJS Act, to implement this BPJS program the duties of BPJS are as follows

a. Conduct and / or accept Participant's registration;

b. Collect and maintain the member's due

c. Receiving the dues contributions from the Government;

d. Manage Social Security Funds for the benefit of the member;

e. Collecting and managing the dat of Social Security program ;

f. Paying the Benefits and / or financing the health services in accordance with the provisions of the Social Security program; and

g. Provide the information on the implementation of Social Security programs to the member and the public.

The National Health Security (JKN) is a government health service program in the form of BPJS Health and BPJS Employment where the system uses the insurance system (compulsory social insurance). BPJS was formed to organize the social security. The definition of social security is broader than the definition of social insurance (compulsory). [3] But the social insurance (compulsory) is one of the method of social security implementation. The characteristics of social insurance (mandatory) are :[4]

1) Organized as stipulated by laws and regulations;

2) The engagement that takes place between the parties is born because the law requires;

3) having a compulsory nature for those who meet the requirements of the relevant legislation;
4) In general, acting as the guarantor or the insurer is the government;

6) Preferably protection of social risk-related matters rather than individual risk; Aimed at providing social security to a community or community group, and not intended for profit;

7) The comparison between premiums and benefits is regulated progressively;

8) The amount of premiums stipulated by the government with laws and regulations, and more determined to the social justice than private equity; and

9) There is no choice concerning the matter of interests and events (evenement)

The regulation of the Minister of Health No. 71/ 2013 on Health Service In JKN, in general, the service flow of BPJS is that BPJS member when conducting medical examination, including in the case of drug taking, perform simple health laboratory checks and dental health examiner can be done at Primary Healthy Facilities (Faskes I) and which include Faskes I or PPK 1 (first-rate health care providers) are as follows:
a. Public Health Center
b. Clinic
c. Class D hospitals (Hospitals established in disadvantaged villages, borders or islands)
d. Practice Doctors or dentists.

Moreover, when the 1st Healthy Facility can provide a reference to 2 nd Healthy Facility then to 3rd Healthy Facility depends on the seriousness of the disease or the completeness of the facilities owned by the Healthy Facility. Advanced grade referrals are the primary primary clinics, general hospitals and specialized hospitals. After that each faskes can file a claim to the local BPJS. BPJS member not have to go through stage I if the situation of the participants 
of BPJS have been classified emergency or emergency.

Based on The regulation of the Minister of Health No. 28 Year 2014 About Guidelines for Implementation of National Health Insurance Program, in chapter IV on health services mentioned that the benefits that are not guaranteed in the JKN program include:

1. Health services conducted without procedure as stipulated in the applicable regulations;

2. Health services performed at Health Facilities that are not cooperated with BPJS Health, except in an emergency;

3. Health services guaranteed by occupational accident insurance programs against illness or injury resulting from work or occupational accidents;

4. Health services that have been guaranteed by a traffic accident insurance program that is mandatory to the value covered by the traffic accident insurance program;

5. Health services conducted abroad;

6. Health services for aesthetic purposes;

7. Services to overcome infertility;

8. Tooth service (orthodontics);

9. Health disorders due to deliberate self-harm, or the consequences of doing selfharmful hobbies;

10. Complementary, alternative and traditional medicine, including non-medical acupuncture, shin she, chiropractic, which have not been declared effective based on health technology assessment;

11. Treatment and medical actions categorized as experiments (experiments);
12. Contraceptives, cosmetics, baby food, and milk;

13. Household health supplies;

14. Health services due to disasters during emergency response, extraordinary events / epidemics;

15. The cost of health services on preventable adverse events ;. The intended preventable adverse events are injuries relating to errors / omissions of medical management including therapeutic and diagnostic errors, improper equipment and so on, except for the associated illness complications.

\section{IMPLEMENTATION OF ARTICLE 4 OF THE BPJS ACT AS INCREASED ACCESS TO HEALTH FACILITIES FOR THE MEMBER OF BPJS}

In Article 4 of the BPJS Act, it is explained that BPJS organizes a national social security system based on mutual benefit, non-profit, transparency, prudence, accountability, portability, mandatory membership, trust fund and guaranteed fund management proceeds used entirely for program development and the amount of interest of participants. Understanding the principle of mutual cooperation is the principle of togetherness among participants in the burden of social security costs so that in the case of BPJS participants experiencing health problems, the replacement of money is realized with the obligation of each participant to pay dues in accordance with the level of salary, wages, or income. This means that BPJS has a mutual cooperation concept, which is one of Indonesian characteristics. BPJS in this case is as a container or institution in managing premiums paid by BPJS member (Insured). The results of this 
premium management which will be used as payment to BPJS member who experience illness or health care. So it can be said that the concept carried by BPJS is from participants to participants. This is also related to the next principle of nonprofit principles. This principle is about business management that prioritizes the use of fund development outcomes to provide maximum benefit for all participants. All premiums received by BPJS will be invested so as to generate maximum profit, where the profit will be used as operating funds in the program BPJS

Still related to the previous principle, the principle of prudence is the principle of managing funds carefully, thoroughly, safely, and orderly. Furthermore, the principle of accountability is the principle of the implementation of the program and financial management is accurate and accountable. These two principles are related to each other. This principle starts from the internal BPJS, there must be internal parties BPJS very understand related to the management of funds (premiums) from BPJS participants to the system of responsibility. All this must be done carefully, safely and thoroughly because the funds being managed are funds from the community. The principle of the trust fund is that the contribution and the result of the development is the depositary fund of the participant to be used as much as possible for the benefit of the social security participants. Another principle is the principle of guarantee fund management outcome is used entirely for the development of the program and the amount of interest of the participants is the principle that is more concerned with the interests of the program BPJS and BPJS participants means all activities and the resulting all for the interests of BPJS member.

The next principle is the principle of openness is the principle of facilitating access to information complete, true and clear to each participant. This principle needs to be continuously socialized so that the participants of BPJS understand about their rights and obligations. In practice today many BPJS participants complain about the difficulty of making claims, drugs that are not covered, referral hospital problems, types of diseases that are not on the list of diseases that can be claimed and others. So finally many opinions emerged from the public about the bad service BPJS, which may actually this is due to lack of understanding BPJS participants associated with rights and obligations. Then the principle of portability is the principle of providing sustainable guarantee even though the participants move jobs or residence within the territory of the Republic of Indonesia. The principle of participation is mandatory is a principle that requires the entire population to be Social Security participants, which is implemented in step by step.

In addition to the above mentioned principles that need to be in the spotlight is the principle of portability. Implementation of Article 4 of this BPJS Act needs to be applied in improving services performed BPJS especially in this case the principle of portability. This principle is often disputed by BPJS participants because of the related health care they get. The purpose of this portability principle is so that the participants of BPJS can still be protected its rights even though move the workplace or move the residence on the inside or outside the city and while still in the territory of the Unitary State of the Republic of Indonesia. In practice, this principle is not implemented given that the BPJS healthy facility system is tiered and in line with the residence of the BPJS participants. If the participant BPJS moved domicile, then still BPJS participants must take care of administrative purposes such as ID cards or family cards in accordance with the new residence. So this is what makes BPJS services tend to be complicated and 
troubles BPJS participants. The implementation of this principle is also not optimal in done by BPJS.

In addition to the above principles, in the national social security system, especially for BPJS Health, cannot be separated from the principles that exist in the insurance. In general, the principle in the insurance is divided into 4 . The first principle of good faith that every party should have good faith in every insurance agreement. The Insured and the Insurer must be good at the beginning of the agreement, the process and until if there is a dispute. The second principle is the principle of indemnity, the principle relating to the balance, that when the insured experiences an uncertain event, the insurer will return the position or condition of the insured into a condition or position before the occurrence of uncertain events. The insured is not allowed to take advantage of the uncertain events he or she experienced. This is because the purpose of the insurance is to divide the risk not to benefit one party. The next principle is the principle of interest that is the principle governing who the right parties to obtain compensation or benefit from the insurer for the uncertain events that have occurred. Not allowed if there are other parties who have no interest in loss or loss suffered gain. This means that payment of claims made by the insurer must be on target. The last principle is the principle of subrogation, this principle is a principle that involves a third party to take responsibility for the loss suffered by the insured because he who caused the loss. [5]

\section{CONCLUSION}

The Implementation of Article 4 of the BPJS Act has not been done maximally so that in practice this makes the existing service on BPJS not run in accordance with the function and purpose of the existence of BPJS. Improving the service and quality of BPJS must be in accordance with what has been regulated in the BPJS Act so that there needs to be technical improvements in practice. One of them is to adjust the principles that exist on the BPJS including general principles in insurance law with the technicalities that exist in practice. Improving BPJS internal system means that in terms of financial management obtained from premium BPJS participants must be set and reported well, orderly and transparent. In addition BPJS external system is at the time BPJS associated with other parties, especially to BPJS member. The service and technical health insurance that can be made as easy as possible so as not to distress the BPJS member. So if it can be improved then BPJS can be a better health insurance institution.

\section{REFERENCES}

[1] SJSN,Pembentukan BPJS, http://www.jamsosindonesia.com/sjsn/bpjs, accessed on April

$5,2017$.

[2] Ilyas IStianur Praditya,BPJS Keshata Bakal Rugi Rp. 7 triliun di Akhir 2015, http://bisnis.liputan6.com/read/2311503/bpjs

-kesehatan-bakal-rugi-rp-7-triliun-di-akhir2015, accessed on April 6, 2017.

[3] Mujibussalim and others, 'Jaminan Sosial Kesehatan: Integrasi Program Jaminan Kesehatan Aceh Dalam Sistem Jaminan Sosial Nasional (2010)' 229.

[4] Arief Suryono and others, 'Asuransi Kesehatan Berdasarkan Undang-Undang Nomor 3 Tahun 1992' (2000) 1213.

[5] Djoko Prakoso, 'Hukum Asuransi Indonesia', Jakarta: Rineka Cipta, (2004) 189. 
